\title{
AGAMA, KEPERCAYAAN, DAN KELESETARIAN LINGKUNGAN STUDI TERHADAP GAYA HIDUP ORANG RIMBA MENJAGA LINGKUNGAN DI TAMAN NASIONAL BUKIT DUA BELAS (TNBD)-JAMBI
}

\author{
Syamsudhuha Saleh \\ Fakultas Ushuluddin dan Filsafat UIN Alauddin Makassar \\ Email: munawir.amansyah@gmail.com
}

\begin{abstract}
This paper analyzes the contribution of people living in the Forest (Orang Rimba) in environmental conservation, particularly forest. Orang Rimba is a group of people living in the forest. They have traditions, norms, beliefs and religion as a basis for their interactions both with other members of the group and with environment. One of these beliefs and norms is the beliefs of animism. The implementation of such beliefs with respect environmental preservation is banning to make pollution in the river without garbage and waste dump on it; destroying ecosystem in the river by catching fish using poison; no waste disposal anywhere; disallowing cutting trees; disallowing of selling woods and fields for non-residents.
\end{abstract}

Keywords: Religion, forest, Orang Rimba, Environment

\begin{abstract}
ABSTRAK
Artikel ini mengkaji tentang peran kepercayaan orang Rimba dalam menjaga dan melestarikan lingkungan terutama hutan. Orang Rimba adalah sekelompok suku yang hidupnya di hutan rimba. Mereka memiliki adat, norma, kepercayaan atau agama yang menjadi acuan dalam berinteraksi baik dengan sesama manusia maupun dengan lingkungan (alam). Diantara kepercayaan mereka adalah kepercayaan terhadap dewa-dewa, makhluk halus serta roh para leluhur. Dalam menghargai kepercayaan tersebut, orang Rimba memiliki beberapa larangan dan pantangan yang ada relevansinya dengan pelestarian lingkungan yakni tidak mengotori sungai dengan membuang air besar, kecil maupun kotoran; tidak merusak ekosistem di sungai dengan melakukan penangkapan ikan menggunakan racun; tidak membuang sampah sembarangan; tidak boleh menebang pohon; serta tidak menjual kayu dan ladang pada non-resident (orang luar).
\end{abstract}

Kata Kunci: Agama, Hutan, Orang rimba, Lingkungan 


\section{Syamsudhuha Saleh -- Agama, Kepercayaan, dan Kelestarian Lingkungan Studi terhadap Gaya Hidup Orang Rimba Menjaga Lingkungan di Taman Nasional Bukit Dua Belas (TNBD)-Jambi}

\section{PENGANTAR}

Isu pemanasan global akibat krisis pencemaran lingkungan merupakan isu aktual yang perlu diperhatikan. Pemanasan global atau yang biasa disebut dengan global warming adalah suatu proses meningkatnya suhu rata-rata atmosfer, laut, dan daratan Bumi. Isu pemanasan global ini menjadi perhatian dunia sejak PBB menyuarakan nya dengan membentuk Intergovernmental Panel on Climate Change (IPCC) pada tahun 1988. IPCC sebuah panel ilmiah yang terdiri dari para ahli klimatologi untuk mengkaji perubahan iklim. (Susanta dan Sutjahjo, 2007: 22). Pemanasan global bukan hanya mengancam kelestarian lingkungan saja, tetapi kehidupan umat manusia dan dunia telah terancam. Hal itu dibuktikan dengan adanya pencairan es di kutub utara dan kutub selatan, polusi udara, pencemaran sungai, perusakan hutan yang mencapai ribuan hektar dan lain-lain. Para ilmuan menyatakan bahwa pemanasan global yang terjadi dalam kurun 50 tahun terakhir ini 90\% diakibatkan oleh ulah manusia sendiri (SOS, 2011: 124). Hal ini menjadi keprihatinan tersendiri bagi umat manusia sebagai penghuni bumi. Isu lingkungan yang bisa di bilang sudah kritis ini mengundang keprihatinan berbagai pihak, salah satunya Intergovernmental Panel on Climate Change (IPCC). Agama pun sudah mulai terjun untuk berusaha mencegahnya. Akan tetapi, sejauh ini agama-agama yang ada diyakini belum mampu memberikan solusinya.

Agama yang ada seharusnya mampu menjawab isu-isu aktual semacam pencemaran lingkungan ini. Kenyataannya, akhir-akhir ini agama justru malah menjadi sumber konflik. Menurut Abdul Munir Mulkhan, sebenarnya kekerasan atas nama agama atau atas nama Tuhan bukan persoalan hubungan antaragama atau antarpemeluk agama yang berbeda, melainkan antarmanusia itu sendiri. Sebagai sistem kepercayaan umat manusia agama semestinya mampu memberikan kontribusi yang nyata terhadap isu-isu aktual yang berkembang di tengah-tengah masyarakat tersebut (Mulkhan, 2007: 72). Bukan malah membisu seribu bahasa. Inilah fenomena yang terjadi di sekeliling kehidupan saat ini. Agama-agama yang diakui oleh pemerintah Indonesia seperti Hindu, Budha, Islam, Kristen, Katolik, dan Kong Hu Chu belumlah mampu memberikan solusi yang nyata terhadap isu-isu aktual yang berkembang di tengah-tengah masyarakat, salah satunya isu mengenai pencemaran lingkungan. Padahal lingkungan merupakan sumber kehidupan umat manusia. Tanpa lingkungan yang sehat mustahil manusia dapat hidup dengan baik. Memang benar, semua agama-agama di dunia yang ada sudah mengingatkan umatnya agar hati-hati dalam memelihara lingkungan. Sayangnya hal tersebut berhenti pada tataran teks semata. Sehingga peringatan tuhan yang ada di kitab-kitab suci menjadi bisu dan mati (Yusuf, 2004). Maka tidak heran, seolah-olah agama dan kitab suci yang ada tidak mampu bersuara. Bukan berarti ini menggambarkan agama dan kitab sucinya yang salah. Akan tetapi, pemahaman dan praktik pengamalannya yang perlu ditinjau ulang.

Berbeda dengan agama-agama tersebut di atas, Sistem Kepercayaan Orang Rimba yang "tidak diakui" oleh dunia yang ada di Taman Nasional Bukit Dua Belas (TNBD), Jambi, memiliki fungsi dan peran yang cukup fital dalam menjaga kelestarian lingkungan. Sistem kepercayaan orang rimba ini mampu hidup dan berhasil menjaga agar lingkungan yang ada tetap lestari dan sehat untuk dihuni oleh para penduduknya. Inilah yang menarik untuk dikaji. Artikel ini berusaha untuk mengurai seperti apakah sistem kepercayaan orang rimba dan bagaimanakah sistem kepercayaan orang rimba tersebut dapat berfungsi dalam menjaga kelestarian lingkungan yang ada. Penelitian ini di harapkan mampu menjadi acuan di mana agama seharusnya berperan dalam menjaga umat manusia dan alam semesta.

\section{Asal-Usul Orang Rimba}

Orang Rimba adalah sebutan bagi sekelompok suku yang hidupnya di hutan 
rimba. Orang Rimba adalah suku yang hidupnya tergantung pada hutan (Purnomo dkk., 2013: 2). Mereka lahir, tumbuh dan berkembang biak di dalam hutan rimba. Mereka hidup dengan aturan, norma, dan adat-istiadat yang ada di hutan rimba (Zuhdi, 2013: 1). Orang rimba sering disebut juga dengan istilah Suku Anak Dalam (SAD), Suku Kubu, Komunitas Adat Terpencil (KAT) dan Orang Rimba. Pada kesehariannya, mereka sering disebut sebagai "Orang Rimbo". Pemerintah mendefinisikan Komunitas Adat Terpencil (KAT) sebagai komunitas masyarakat yang hidupnya secara berkelompok dalam kesatuan-kesatuan (unit) sosial budaya yang bersifat lokal dan terpencar di dalam hutan dan pinggiran sungai, serta kurang atau belum terlibat dalam jaringan pelayanan sosial, ekonomi, dan politik dari pemerintah (Najiyati, dkk., 2005: 22).

Mereka lebih nyaman jika disebut "Orang Rimba". Belum dapat diketahui secara pasti kapan penggunaan kata "orang rimba" ini muncul (Zuhdi, 2013: 2). Sebutan "orang rimba" menurut mereka lebih manusiawi karena jika dibandingkan dengan sebutan "Orang Kubu”. Makna kata "Orang Rimba" lebih memiliki makna penghargaan dan penghormatan. Mereka sendirilah yang menamai diri mereka sebagai orang rimba atau mereka menyebut diri mereka sendiri dengan istilah 'orang rimbo'. Sedangkan untuk Suku Anak Dalam lebih merupakan sebutan yang diberikan oleh pemerintah. Walaupun di dalam struktur orang rimba sendiri ada jabatan 'Anak Dalam', tetapi kata "suku" lebih identik dengan julukan yang diberikan oleh orang luar (Zuhdi, 2013: 2).

Sedangkan sebutan "Orang Kubu" merupakan sebutan yang diberikan kepada orang rimba oleh masyarakat pedesaan atau masyarakat luas. Berbeda dengan istilah Orang Rimba, Suku Anak Dalam, dan Komunitas Adat Terpencil, istilah "Kubu" menurut orang rimba mengandung konotasi negatif. Kata "Kubu" lebih menggambarkan kepada cerminan kebodohan dan keterbelakangan. Oleh karena itu, suku ini tidak senang jika dipanggil atau dijuluki sebagai orang kubu. Selain cerminan kebodohan dan keterbelakangan, sebutan "Kubu" bagi orang-orang rimba mengandung makna merendahkan dan menghinakan. Maka tidak heran jika mereka menjadi marah jika disebut dengan istilah orang kubu (Simanjuntak, 2008: 9).

Pertanyaan yang kemudian muncul adalah, sejak kapan orang rimba ada dan bagaimanakah sejarah munculnya orang rimba? Berbicara mengenai asal- usul munculnya orang rimba cukup rumit karena di dalamnya mengundang banyak perdebatan mengenai asal usulnya. Sebagian mengatakan bahwa orang rimba sudah ada sejak hutan rimba itu ada. Ada juga yang mengatakan bahwa orang rimba sudah ada sejak adanya penjajahan di Indonesia. Sedangkan pendapat yang lainnya mengatakan bahwa orang rimba sudah ada sejak kerajaan-kerajaan yang keberadaannya sudah berabad-abad lamanya jauh sebelum datangnya penjajahan (Zuhdi, 2013: 2).

Akan tetapi, di antara pendapat yang ada di atas, pendapat yang dianggap paling kuat adalah pendapat yang terakhir, yaitu menurut M.Nurdin Zuhdi, orang rimba sudah ada sejak berabad-abad, jauh sebelum penjajahan Belanda datang ke Nusantra. Bahkan dari hasil wawancara yang dilakukan oleh Nurdin kepada Tumenggung Tarip. Tumenggung Tarip adalah satusatunya Tumenggung orang rimba yang pernah mendapatkan penghargaan Kehati Award dan Kalpataru. Tumenggung Tarib berasal dari Desa Pematang, Kecamatan Air Hitam, Kabupaten Sarolangon, Jambi. Dia menjadi Tumenggung orang rimba di kelompok Air Hitam Taman Nasional Bukit Duabelas. Kata "Tumenggung" adalah julukan yang diberikan kepada pemimpin orang rimba. Jabatan Tumenggung setara dengan Gubernur. Tidak semua orang rimba bisa menjadi Tumenggung. Hanya orangorang tertentu yang dianggap mampu untuk menjadi pemimpin orang rimba. Dikarenakan memang syarat untuk menjadi Tumenggung dalam kelompok orang rimba tidaklah 
mudah, salah satunya dia harus memilki keilmuan yang mendalam. Selain dianggap sudah "sakti", seperti memiliki kekebalan tubuh, seorang calon Tumenggung harus memiliki wawasan ilmu keadatan yang luas. Seorang Tumenggung juga harus memiliki ketenangan dan kebijaksanaan dalam bersikap.

Orang rimba merupakan keturunan dari kerajaan-kerajaan yang dulu pernah ada di Indonesia, seperti kerajaan Sriwijaya yang selama ini diyakini berada di sekitar Palembang dan Jambi, Sumatra. Menurut informasi yang di dapat, orang rimba dahulu merupakan rakyat dari sebuah kerajaan yang memberontak. Kemudian mereka diperangi sehingga mereka melarikan diri dan bersembunyi di dalam hutan. Karena sudah lamanya mereka sembunyi dan hidup di hutan rimba, mereka lama kelamaan betah dan terbiasa hidup di hutan rimba dan jadilah orang rimba. Sejak saat itulah orang rimba ada sampai sekarang. (Zuhdi, 2013: 5).

Orang rimba yang dikaji dalam artikel ini merupakan orang rimba yang bermukim di Taman Nasional Bukit Dua Belas (TNBD) Propinsi Jambi. TNBD merupakan salah satu hutan yang ada di Sumatra yang beriklim tropis. Secara geografis, TNBD terletak di antara 10231'37-10248'27 BT dan 144'35203'15' LS. Sedangkan secara administratif, TNBD terletak di antara tiga kecamatan dan satu kabupaten. Di sebelah Utara terletak di Kecamatan Marosebo Ulu Kabupaten Batanghari. Di sebelah Timur, TNBD terletak di Kecamatan Batin XXIV Kabupaten Batanghari. Di sebelah Selatan, TNBD terletak di Kabupaten Sarolangun dan di sebelah Barat terletak di Kecamatan Tebo Ilir Kabupaten Tebo. Secara keseluruhan kawasan taman nasional bukit duabelas (TNBD) memiliki luas 60.500 ha. Hal tersebut didasarkan pada Surat Keputusan Menhutbun No. 258/KptsII/2000 Tanggal 23 Agustus 2000 tentang alih fungsi hutan. Penetapan TNBD seluas 60.500 ha ditunjuk dengan Surat Keputusan Menteri Kehutanan dan Perkebunan Nomor: 258/Kpts-II/2000 Tanggal 23 Agustus 2000 tentang alih fungsi hutan. (Kementerian Ke hutanan Direktorat Jenderal Perlindungan Hutan, 2011: 3). Penetapan tersebut terutama diperuntukkan untuk perlindungan bagi Orang Rimba sebagai indigenous people di kawasan tersebut. Saat ini pengelolaan taman berada di tangan Dinas Konservasi Sumber Daya Alam (BKSDA) (Muzakki, 2013: 6).

\section{PEMBAHASAN \\ Sistem Kepercayaan Orang Rimba}

Berbeda dengan agama-agama yang ada - Islam, Kristen, Katolik, Hindu, Buddha, dan Kong Hu Chu (Hendropuspito: 188). Sistem kepercayaan orang rimba tidak memiliki nama tertentu. Mereka hanya mengenal adanya kekuatan di luar kemampuan dirinya. Kalau mereka ditanya nama agama, maka mereka tidak dapat menyebutkan namanya karena memang sistem kepercayaan orang rimba tidak memiliki nama yang khas. Heddy Shri Ahimsa Putra membedakan antara agama dengan sistem kepercayaan. Heddy mengegaskan bahwa dilihat dari sudut pandang tertentu makna 'agama' lebih luas daripada sistem kepercayaan, tetapi dilihat dari sudut pandang yang lain sistem kepercayaan lebih luas maknanya dari pada agama. Heddy lebih condong pada pendapat yang pertama bahwa ia menganggap pendapat pertamalah yang masih paling cocok untuk memahami gejala sosial-budaya yang disebut 'agama' (Putra, 2009: 16-17). Mereka hanya menyebut "kepercayaan". Kepercayaan yang dimaksud adalah kepercayaan terhadap kekuatan yang ada di luar kemampuan manusia. Mereka memiliki kepercayaan terhadap adanya dewa-dewa, makhluk halus dan para roh leluhur. Kepercayaan orang rimba terhadap adanya dewa atau makhluk halus menggambarkan suatu teori animisme. Teori tentang animisme ialah suatu teori yang beranggapan bahwa asal mula dan dasar daripada suatu religi manusia itu adalah kepercayaan akan adanya makhluk-makhluk halus dan roh-roh yang menempati seluruh alam (Koentjaraningrat, 1958: 148). Akan tetapi, bukan berarti orang rimba mengatakan bahwa tuhan mereka 
adalah dewa. Mereka memuja dewa bukan untuk menyembahnya, melainkan hanya sebagai perantara antara dewa dan Tuhan yang Maha Esa saja.

Orang rimba mempercayai adanya para dewa dan fungsi dewa hanyalah sebagai perantara kepada Tuhan. Jika mereka ditanya siapakah tuhan orang rimba? Mereka hanya menjawab bahwa tuhan ada di atas langit. Tuhan adalah yang menciptakan alam semesta dan seluruh isinya. Tuhan tidak tidur. Tuhan selalu menjaga dan mengawasi umat manusia seperti yang dituturkan oleh Tumenggung Nggrip di Kedundung Muda, TNBD pada Desember 2013. Tumenggung adalah sebutan bagi pemimpin orang rimba. Ada beberapa dewa yang diyakini keberadaannya oleh orang rimba. Para dewa ini selain sebagai perantara kepada tuhan, peran dewa salah satunya adalah menjaga dan dijadikan tempat perlindungan dan pertolongan oleh orang rimba.

Ada lebih dari seratus dewa yang diyakini oleh orang rimba. Setidaknya hanya ada sekitar delapan dewa yang paling sering dijadikan tempat pertolongan bagi orang rimba. Di antaranya adalah dewa Harimau, Dewa Trenggiling, Dewa Gajah, Dewa Kucing, Dewa Huluaye, Dewa Madu, Dewa Penyakit, dan Dewa Padi (Zuhdi: 8). Setiap dewa memiliki tugas dan perannya masing-masing. Dewa Harimau bertugas menjaga hutan. Selain menjaga hutan dewa harimau ini juga bisa mengobati penyakit. Dewa Trenggiling yang bertempat tinggal di Gunung diyakini dapat menolong orang rimba dalam mengobati segala penyakit. Selain itu, dewa ini juga dimintai pertolongan untuk memberikan petunjuk. Misalnya tentang hari-hari baik untuk menanam atau melakukan perjalanan jauh. Peran Dewa Gajah pun serupa dengan dewa Trenggiling, yaitu dijadikan tempat meminta pertolongan bagi orang-orang rimba yang sakit. Dewa Kucing, dewa ini merupakan dewa yang berbeda dari dewa-dewa sebelumnya. Selain dapat memberi petunjuk untuk mengobati orang sakit, dewa ini lebih berfungsi sebagai perantara atau pengantar untuk menemui dewa yang lainnya. Dewa Huluaye, dewa ini bertugas untuk memberitahu kejadiankejadian yang akan terjadi. Seperti adanya musibah, kecelakaan atau juga bisa memberitahu kalau besok adalah hari yang baik untuk berburu. Dewa Madu adalah dewa yang diyakini sebagai pemberi rezeki melimpah berupa madu pada Pohon Si alang. Pohon-pohon Si alang yang ada madu nya diyakini dijaga oleh dewa-dewa madu. Dewa Penyakit tugasnya adalah memberikan penyakit tertentu kepada tanaman atau bahkan kepada manusia. Sebaliknya, dewa ini juga bisa menghindarkan tanaman dan manusia dari penyakit. Dia hanya memberikan penyakit untuk manusia yang jahat (Zuhdi: 8-11). Sedangkan yang terakhir adalah Dewa Padi atau juga bisa disebut dengan dewa buah tuganya adalah menjaga Padi dan buah-buahan yang ada di hutan rimba.

Dewa padi juga disebut dewa buah yang memiliki peran sangat penting dalam menjaga hutan. Dewa inilah yang menjadi bagian dari sistem kepercayaan orang rimba yang berperan penting dalam menjaga keseimbangan lingkungan. Dewa buah ini adalah dewa yang paling berjasa karena buah-buahan dan air menurut kepercayaan orang rimba di jaga oleh dewa buah ini.

\section{Peran Agama dalam Menjaga Lingkungan}

Teori animisme dari A. W. Nieuwenhuis, sebagaimana yang dikutip oleh Koentjaraningrat, cocok untuk menggambarkan sistem kepercayaan orang rimba. Menurut Nieuwenhuis bahwa teori agama manusia itu berpangkal kepada kesadaranan akan adanya makhlusmakhluk halus yang menempati seluruh alam semesta (Koentjaraningrat: 194). Kepercayaan orang rimba terhadap adanya para dewa merupakan bagian dari sistem kepercayaan orang rimba yang dapat digolongkan kepada teori animisme ini.

Kemudian hubungan kepercayaan orang rimba ini terhadap kelestarian lingkungan, berupa Kepercayaan yang tertanam di dalam hati orang-orang rimba memberikan 
kekuatan untuk tidak melanggar aturan dan larangan-larangan yang ada sehingga ketaatan terhadap ajaran agamanya ini mampu menjadi pengendali diri dalam mematuhi semua ajaran yang ada dalam sistem kepercayaan tersebut. Agama yang ditaati mampu menjadi pengendali prilaku (Sugiharto, 2005: 50). Kekuatan keimanan terhadap agama tersebut menjadi mesin pengontrol diri yang ampuh. Hal inilah yang seharusnya juga tercermin di dalam setiap umat pemeluk agama.

Orang rimba sangat terkenal dengan ketatnya peraturan yang ada di dalam sistem kepercayaannya. Ada beberapa larangan atau di dalam istilah suku rimba lebih sering disebut dengan istilah "pantangan" yang berlaku di dalam orang rimba. Pantanganpantangan yang diajarkan di dalam sistem kepercayaan orang rimba yang berkaitan langsung dengan kelestarian lingkungan di antaranya seperti larangan buang air besar di sungai, kencing di sungai, membuang sampah baik di darat maupun di sungai, menebang pohon, menjual kayu dan ladang kepada orang luar, menangkap ikan dengan racun, dan lain-lainnya berdasarkan hasil Wawancara dengan Meranggai (anak dari wakil Tumenggung Jalau) di Kedundung Muda pada Desember 2013.

Disebut "pantangan" karena memang aturan tersebut sangat dilarang. Jika di langgar maka hukumnya sangat berat. Salah satunya adalah kepercayaan adanya kutukan dewa buah. Jika dewa buah sudah marah orang rimba meyakini akan ada bencana berupa rusaknya buah-buahan yang ada di dalam hutan. Baik dalam bentuk tidak berbuah, buahnya sedikit, atau buahnya rusak karena Hama. Menurut mereka hal tersebut dikarenakan adanya pelanggaran terhadap pantangan-pantangan tersebut.

Orang rimba menggantungkan kehidupannya terhadap hutan, baik itu dari berburu maupun buah-buahan yang ada di dalam hutan. Jika terjadi kerusakan terhadap sumber kehidupan nya maka hidup orang rimba terancam. Hal inilah yang sangat dikuwatirkan oleh orang rimba. "orang rimba hidupnya bergantung kepada hutan. Orang rimba makan dengan berburu babi, rusa, kancil, burung, ikan. Kalau hutan ditebang dan rusak, mati lah orang rimba" (Wawancara dengan Beteduh di Kantor WARSI kelompok Kedundung Muda TNBD pada Desember 2013).

Orang rimba sangat cemas akan semakin rusaknya hutan karena bagi mereka hutan adalah rumah. Hutan merupakan tempat tinggal satu-satunya bagi orang rimba. Orang rimba tidak bisa hidup di luar hutan rimba sebagaimana orang-orang luar pada umumnya. Hal tersebut terbukti ketika Pemerintah Jambi menyediakan perumahan yang diperuntukkan bagi orang-orang rimba di perbatasan antara desa dengan hutan TNBD kelompok Kedundung Muda. Pada tahun 2013 pemerintah Propinsi Jambi telah menyediakan sekitar tiga puluh rumah untuk orang-orang rimba. Akan tetapi sampai saat ini orang-orang rimba masih sulit menempati nya. Mereka lebih memilih membuat gubuk kecil di samping rumah tersebut yang ber atap kan dedaunan kelapa sawit. Mereka lebih nyaman hidup berdampingan dengan alam walaupun penuh kesederhanaan. Hal ini menjadi tanda bahwa masih sulit mengajarkan orang-orang rimba untuk belajar hidup sebagaimana orang-orang luar pada umumnya.

\section{Pantangan Buang Kotoran di Sungai}

Pantangan pertama yang di bahas dalam kajian ini adalah pantangan mencemari lingkungan. Ada beberapa larangan yang ada di dalam sistem kepercayaan orang rimba yang harus ditaati sepenuhnya. Larangan tersebut adalah mengotori lingkungan. Lingkungan yang dimaksud adalah hutan dan sungai. Orang rimba memiliki peraturan atau pantangan membuang sampah plastik baik itu di darat maupun di air. Menurut orang rimba jika ada sampah atau kotoran berupa plastik maka harus langsung dibakar di tempat berdasarkan Wawancara dengan Meranggai di Kedundung Muda TNDB pada Desember 2013. Walaupun sampah tersebut adalah bungkus permen yang kecil. 
Ketika penulis berkunjung di Kedundung muda pada Desember tahun 2013 penulis mendapatkan pengalaman berharga tentang pentingnya membakar sampah plastik sekecil apa pun bentuk sampah tersebut. Jika pada saat itu penulis tidak mematuhi peraturan, maka penulis bisa diusir dari Kedundung Muda dan orang rimba tidak berkenan menerima tamu dari luar yang tidak dapat mentaati peraturan yang diberlakukan di dalam rimba.

Selain dilarang membuang sampah plastik sembarangan, penulis juga diajarkan tentang larangan buang air besar, dan kecil di dalam air atau di sungai. Jika ketahuan buang air besar di sungai pada saat itu pula dapat langsung di usir dan tidak boleh masuk ke dalam hutan wilayah orang rimba. Ketika penulis bertanya kenapa tidak boleh buang air besar di sungai? mereka menjawab, "nanti dewa bisa marah" berdasarkan Wawancara dengan Beteguh pada 9 Agustus 2014. Kepercayaan terhadap kutukan dewa inilah yang menjadikan orang rimba tidak berani melanggar norma-norma yang berlaku di dalam sistem kepercayaan orang rimba.

Orang rimba meyakini jika sungai di cemari dengan kotoran maka Dewa Buah bisa marah. Kalau dewa yang diyakini tersebut telah marah maka akan terjadi kutukan. Kutukan tersebut berupa pohon yang berbuah tidak dapat lagi berbuah atau kalaupun berbuah buahnya sedikit atau buahnya rusak di makan hama. Kerusakan buah-buahan tersebut bagi mereka adalah karena adanya kutukan buah hal tersebut disebabkan adanya orang yang buang air besar di sungai.

\footnotetext{
"Saat orang rimba sudah memuja dewa buah, maka orang jangan lagi berak di sungai. Kalau berak di sungai itu musim buah yang datang tidak menjadi sempurna. Misalnya buahnya berkurang atau kurang sehat (kurang segar), itulah akibatnya rugi tidak makan buah dan minum air kotor" (Wawancara dengan Beteguh pada 9 Agustus 2014).
}

Selain buahnya yang tidak sempurna karena rusak kutukan dewa bagi orang yang buang air besar di sungai di antaranya adalah orang yang buang air besar tersebut tidak dapat buang air besar lagi. Hal tersebut diyakini oleh orang rimba akibat kutukan dewa buah yang marah karena sungainya di cemar. Mungkin hal tersebut secara logika dapat dikarenakan air yang diminum sudah tercemari dan buah-buahnya sudah rusak akibat pencemaran tersebut. Maka tidak heran jika orang yang minum air yang kotor menjadi sakit dan tidak bisa lagi buang air besar. Bagi orang rimba semua itu diyakini akibat kutukan dewa yang marah.

Dikarenakan dilarang buang air besar di sungai, maka orang rimba buang air besarnya di darat. Itu pun jangan sampai buang air besar yang dekat dengan pohon yang buahnya dapat dimakan. Jika buang air besar di dekat pohon yang berbuah maka dewa buah juga bisa marah dan mengutuk orang tersebut. Kepercayaan terhadap adanya dewa yang marah apabila melanggar pantangan-pantangan tersebut maka mereka memberikan rambu-rambu yang kuat dalam menjaga air dan hutan yang ada.

Selain pantangan mencemari sungai, pantangan lainnya adalah menangkap ikan menggunakan racun. Siapa yang melanggar pantangan tersebut maka langsung berhadapan dengan pimpinan orang rimba, Tumenggung. Larangannya ini disebabkan selain ikan yang masih kecil menjadi ikut mati, air yang menjadi sumber kehidupan orang rimba ikut tercemar i. Hal inilah yang menyebabkan mengapa orang rimba sangat melarang menangkap ikan dengan racun atau bius.

\section{Pantangan Menebang Pohon}

Selain pantangan yang sudah dijelaskan di atas, ada pantangan lainnya yaitu pantangan menebang pohon. Orang rimba melarang penduduknya untuk sembarangan menebang pohon. Orang rimba menjadikan pohon-pohon yang ada di hutan tetap tumbuh besar dan terjaga. Salah satu pohon yang dilarang untuk ditebang adalah 
pohon Si alang, pohon Singgris, dan pohon Sentubung.

Pohon Si alang merupakan pohon yang tingginya bisa mencapai ratusan meter. Pohon ini dilarang ditebang karena pohon ini berfungsi sebagai sarang lebah yang madu nya menjadi salah satu sumber kehidupan orang rimba. Maka tidak heran jika pohon ini sangat dilindungi. Sarang lebah yang ada di pohon Si alang dalam satu pohon bisa mencapai 200 sarang sangat menjanjikan sebagai penghasil madu murni. Jika pohon ini ditebang, maka lebah-lebah yang ada di hutan akan pergi dan orang rimba tidak dapat lagi panen madu.

Pohon Si alang ini pun diyakini oleh orang rimba sebagai salah satu pohon yang dijaga oleh dewa. Dewa yang menjaga pohon Si alang adalah Dewa Madu berdasarkan Wawancara dengan Mangku (wakil Tumenggung) di Kantor WARSI Kelompok Ke dundung Muda TNBD pada Desember 2013. Menurut Mangku, tidak semua orang rimba dapat memanjat pohon Si alang. Hanya orang-orang tertentu yang dapat memanjat pohon ini, yaitu orang yang di anggap sudah berilmu dan orang tersebut harus mampu menghafal mantra sebelum menaiki pohon Si alang ini.

Selain pohon Si alang, pohon yang sangat dilarang untuk ditebang adalah pohon Singgris dan pohon Sentubung. Keduanya pohon ini fungsinya adalah untuk upacara kelahiran bayi orang rimba. Jika ada orang rimba yang melahirkan bayi maka upacara selamatan bayi tersebut menggunakan kedua pohon tersebut. Kulit dari pohon Senggris dilembutkan kemudian ditempelkan di ubun-ubun sang bayi. Sedangkan batang dari pohon sentubung digunakan sebagai tanda tempat ari-ari sang bayi dikuburkan. Kedua pohon ini sangat sakral bagi orang rimba. Maka baik itu orang rimba sendiri maupun orang luar sangat dilarang mendekati apa lagi sampai memotongnya.

Selain pohon-pohon tersebut di atas, orang rimba juga dilarang keras menembang dan menjual pohon ke luar. Jika pantangan seperti ini di abaikan maka sangat mungkin dalam waktu yang tidak lama hutan akan segera habis. Saat ini saja keberadaan hutan di TNBD sudah terancam dengan keberadaan PT-PT yang sudah mulai merambah di sekeliling TNBD. Dari data yang di dapat setidaknya sudah ada sebanyak tujuh perusahaan yang sudah mengepung kawasan hutan TNBD. Perusahaan-perusahaan yang mulai menjarah hutan tersebut di antaranya adalah PT LKU, PT SDM, PT Wana perintis, PT EMAL, PT JAW, PT SAL 1, dan PT SAL 2 (Zuhdi: 3). Data lain juga meneyebutkan bahwa kehadiran Hutan Tanaman Industri (HTI) berdampak buruk pada Hutan Adat Bathin Betuah seluas 98 hektar yang telah ditetapkan dalam SK Bupati Sarolangun Nomor 206 tahun 2010 (Artikel, 2013: 42.). Sejak Bukit Dua Belas disahkan oleh pemerintah sebagai Taman Nasional pada tahun 2001 hutan rimba dan orang rimba sedikit terjaga. Bukan berarti keberadaan mereka tidak terancam sebab berbagai macam cara dapat dilakukan oleh pihak yang memiliki otoritas dan kekuatan. Faktor politik juga dapat mengancam eksistensi orang rimba (Zuhdi: 3-4). 


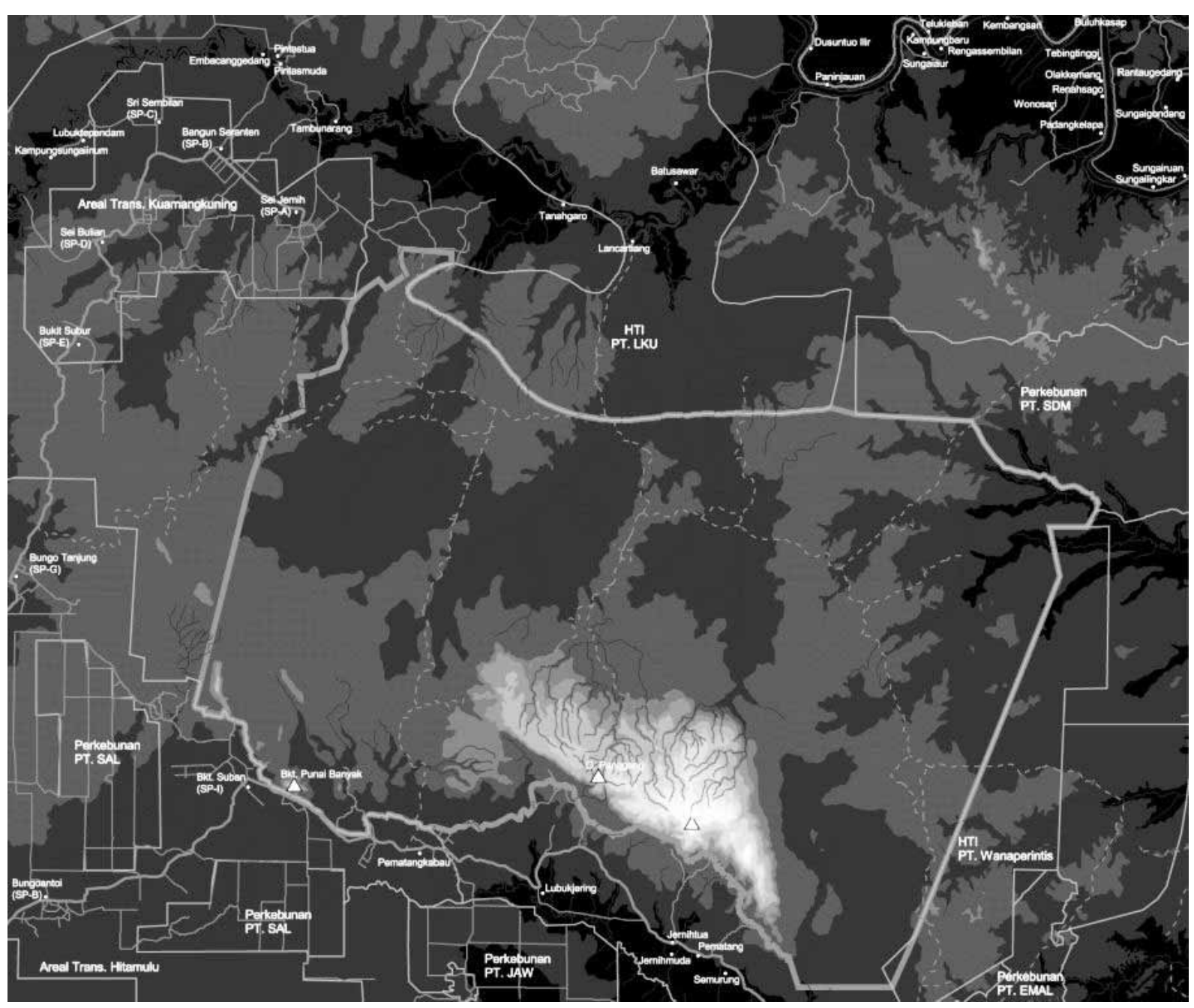

Gambar 1:

Peta Penyebaran Perusahaan-perusahaan (PT) di TNBD. Sumber KKI WARSI, 2013.

Peta tersebut di atas menunjukkan perkembangan PT-PT yang mengancam keberadaan Hutan TNBD. Data ini menunjukkan bawa orang rimba sedang berada dalam ujung kepunahan. Keberadaan mereka sangat terancam. Hal ini tentu sangat memprihatinkan. Hal ini sudah mestinya menjadi keprihatinan pemerintah. Pemerintah memiliki kekuatan untuk mencegah terjadi penjarahan hutan dengan cara membabi buta. Garis yang ada di peta tersebut di atas merupakan batas wilayah TNBD dengan komunitas luar. Sungguh batas yang sudah sangat memprihatinkan (Zuhdi: 3-4).

Setidaknya ada empat fungsi agama, yaitu agama sebagai pembimbing dan petunjuk kehidupan; agama sebagai penolong; agama sebagai penenteram jiwa; dan agama sebagai pengendali moral (Sholeh, 2008: 48). Agama sebagai pengendali moral inilah yang memiliki peran sangat vital dalam kehidupan nyata, terutama yang berkaitan secara langsung dengan lingkungan. Hal inilah yang tampak dari sistem kepercayaan orang rimba. Agama mereka mampu menjelma sebagai pengendali moral sehingga alam sekitarnya pun merasakan kedamaian. Alam lingkungan menjadi aman jika pemeluknya memiliki pengendali moral yang kuat. Krisis moral inilah yang menurut hemat penulis sedang melanda masyarakat dunia. Inilah yang menurut Haidir Hajar bahwa sikap agama tentang 


\section{Syamsudhuha Saleh -- Agama, Kepercayaan, dan Kelestarian Lingkungan Studi terhadap Gaya Hidup Orang Rimba Menjaga Lingkungan di Taman Nasional Bukit Dua Belas (TNBD)-Jambi}

perlakuan yang semestinya dilakukan manusia yang notabene adalah khalifatullah, kepada alam, hampir serupa dengan sikap para penganut paham animism bahwa agama pun melarang manusia menjarah, mengeruk, dan mengeksplotir alam secara liar dan brutal (Widagdo, 2012: 268). Menurur Quraish Shihab, jika agama tidak lagi mampu memberikan keharmonisan dalam kehidupan, maka agama telah mengalami krisis. Jika demikian yang terjadi maka agama tidak lagi memberikan ketenangan bagi pemeluknya, tetapi agama telah menjadi sumber keresahan bagi pemeluknya (Shihab, 2007: 218).

Usaha mencegah terjadinya kerusakan hutan rimba, selain peran agama yang dilakukan oleh orang rimba-baik dengan cara menanamkan "mitos" ke dalam keyakinan orang rimba - yang dilakukan oleh orang rimba adalah dengan cara menanam pohon karet. Kesadaran pentingnya pohon karet kini mulai tumbuh di dalam komunitas orang rimba. Hal ini masih perlu perhatian dan masih perlu dukungan dari pihak pemerintah. Selain untuk mencegah kerusakan hutan, penanaman pohon karet yang dilakukan oleh orang rimba adalah sebagai sumber perekonomian orang rimba. Tujuannya adalah agar orang rimba tidak lagi harus hidup dengan cara berpindahpindah dari satu hutan ke hutan yang lainnya. Tumenggung Tarip yang dianggap sebagai pencetus pertama dalam menjaga hutan dengan cara penanam pohon karet ini. Kegigihannya inilah Tumenggung Tarib sering disebut sebagai "pendekar hutan". Sebutan itu lahir karena perjuangannya dalam menjaga hutan dengan cara menanami hutan dengan pohon karet. Cara ini dilakukan oleh Tarib guna mencegah adanya kerusakan hutan yang dilakukan oleh pembalakan liar yang sampai sekarang masih juga terjadi. Dari perjuangannya inilah ia kemudian dikenal sebagai orang rimba pertama yang merintis konsep penanaman pohon karet atau disebut sebagai Hompongan di hutan rimba TNBD, yaitu kegiatan penanaman pohon karet. Karena kegigihannya inilah kemudian ia diganjar pengharggan Kehati Award dan Kalpataru oleh pemerintah RI pada tahun 2003.

\section{SIMPULAN}

Dari kajian singkat di atas, dapat disimpulkan bahwa sistem kepercayaan yang dianut oleh orang rimba di Taman Nasional Bukit Dua belas (TNBD) menjadi sebuah pengontrol prilaku yang ampuh. Agama yang mereka anut mampu menjelma menjadi mesin pengendali diri yang mampu menjadi penjaga kelestarian alam. Kepercayaan orang-orang rimba terhadap adanya kutukan para dewa terhadap "pantanganpantangan" yang dilanggar inilah yang telah tumbuh dan mengakar kuat di dalam keyakinan mereka. Sehingga agama orang rimba menyatu dalam prilaku kehidupan sehari-hari. Agama tidak lagi hanya sebatas wacana di dataran teks semata. Akan tetapi, agama mampu memberi efek nyata dalam kehidupan mereka. Agama mampu memberikan solusi terhadap persoalan yang dihadapi pemeluknya. Hal ini tentu berbeda dengan fenomena keberagamaan yang telah ada pada umumnya. Di mana agama hanya sebatas teori semata. Agama hanya terhenti pada dataran wacana teksnya. Sehingga tidak heran jika agama menjadi tampak bisu dan tidak berdaya dalam merespon isu-isu aktual yang tengah berkembang di tengah-tengah masyarakat. Ini bukan berarti agamanya yang salah dan perlu ditinjau ulang adalah pemahaman terhadap agama itu sendiri.

\section{DAFTAR PUSTAKA}

Artikel, 2013. "Hutan Adat Sarolangun Terancam" dalam Majalah Alam Sumatera, edisi September.

D. Hendropuspito, O. C., Sosiologi Agama, Yogyakarta: Kanisius, t.th.

Kementerian Kehutanan Direktorat Jenderal Perlindungan Hutan dan Konservasi Alam Balai Taman Nasional Bukit Duabelas. 2011. Buku Informasi Taman Nasional Bukit Duabelas, Jambi: Balai TNBD. 
Koentjaraningrat. 1958. Beberapa Metode Antropologi dalam Menjelidikan2 Masjarakat dan Kebudajaan di Indonesia: Sebuah Ichtisar, Djakarta: Universitas.

Munir Mulkhan, Abdul. 2007. Manusia Alquran: Jalan Ketiga Religiositas di Indonesia, Yogyakarta: Kanisius.

Muzakki, Ahmad. 2013. "Seloko Pesemian Rimba: Kajian Etnografi Tentang Identitas Budaya dan Pelestarian Rimba Taman Nasional Bukit Duabelas Jambi" Laporan Penelitian Short Chourse Metodologi Penelitian Sosial Keagamaan Kementerian Agama RI.

Najiyati, S., Agus Asmana, dan I Nyoman N. Suryadiputra. 2005. Pemberdayaan Masyarakat di Lahan Gambut, Bogor: Wetlands International-IP.

Purnomo dkk. 2013. Buku Bahan Ajar Orang Rimba dan Kebudayaan, Jambi: KKI Warsi.

Putra, Heddy Shri Ahimsa. 2009. “Fenomenologi Agama: Pendekatan Fenomenologi untuk Memahami Agama", dalam Jurnal Penelitian Walisongo. 17(2): 16-17.

Shihab, M. Quraish. 2007. "Membumikan" AlQuran: Fungsi dan Peran Wahyu dalam Kehidupan Masyarakat, Jakarta: Mizan Pustaka.

Sholeh, Moh. 2008. Bertobat Sambil Berobat, Jakarta: Hikmah.

Simanjuntak, Mastum. 2008. Selayang Pandang Anak Lintang Bukit Barisan Suku Tobo atau Kubu, Pematangsiantar: Kolportase Pusat GKPI.

SOS, Team. 2011. Pemanasan Global: Solusi Dan Peluang Bisnis, Jakarta: Gramedia Pustaka Utama.

Sugiharto, Bambang. 2005. “Ilmu dan Agama dalam Kurikulum Perguruan
Tinggi", dalam Zainal Abidin Bagir dkk., (ed.), Integrasi Ilmu dan Agama: Interpretasi dan Aksi, Bandung: Mizan Pustaka.

Susanta, Gatut. dan Hari Sutjahjo. 2007. Akankah Indonesia tenggelam akibat pemanasan global?, Yogyakarta: Niaga Swadaya.

Wawancara dengan Beteduh di Kantor WARSI kelompok Kedundung Muda TNBD pada Desember 2013.

Wawancara dengan Beteguh pada 9 Agustus 2014.

Wawancara dengan Beteguh pada 9 Agustus 2014.

Wawancara dengan Mangku (wakil tumenggung) di Kantor WARSI Kelompok Kedundung Muda TNBD pada Desember 2013.

Wawancara dengan Meranggai (anak dari wakil Tumenggung Jalau) di Kedundung Muda pada Desember 2013.

Wawancara dengan Tumenggung Nggrip di Kedundung Muda, TNBD pada Desember 2013.

Widagdo, Haidi Hajar. 2012. "Relasi Alam dan Agama: Sebuah Upaya Penyelarasan antara Budaya Mistis dengan Pelestarian Lingkungan" dalam Esensia Jurnal Ilmu-ilmu Ushuluddin. 13(2): 268.

Yusup, dkk., Muhammad. 2004. Studi Kitab Tafsir: Menyuarakan Teks yang Bisu, Yogyakarta: Teras.

Zuhdi, M. Nurdin. 2013. “Tuhan, Dimana Kau Berada: Kajian Etnografi tentang Sistem Kepercayaan Orang Rimba di Taman Nasional Bukit Dua Belas, Jambi", Laporan Penelitian Short Chourse Metodologi Penelitian Sosial Keagamaan Kementerian Agama RI. 